\title{
Commitment To Organizations Viewed From Transformational Leadership And Work Satisfaction
}

(Study on Teachers of Private Junior High Schools in Bogor Regency)

\author{
Yasnimar Ilyas $\left.{ }^{*}\right)$ \\ ${ }^{*}$ Sekolah Tinggi Ilmu Ekonomi Dewantara, Bogor, Indonesia \\ Corresponding Author: ilyasyasnimar@yahoo.com
}

\begin{abstract}
This study aims to determine the relationship between Transformational Leadership and Job Satisfaction with Commitment to the Organization. The sample chosen was 240 teachers, with the criteria of Private Junior High School Teachers in Bogor Regency. This study uses a Mixed Method Sequential Explanatory. The results of this study conclude that: a. There is a very significant positive relationship between Transformational Leadership and Commitment to the Organization as indicated by the correlation coefficient $\left(\mathrm{ry}_{1}\right)=0.505$ and the coefficient of determination worth $\left(\mathrm{ry}_{1}\right)^{2}=0.255$ which means Transformational Leadership contributes to $25.5 \%$ commitment to the organization. b. There is a very significant positive relationship between Job Satisfaction and Commitment to the Organization as indicated by the correlation coefficient $\left(\mathrm{ry}_{2}\right)=0.618$ and the determination coefficient of $\left(\mathrm{ry}_{2}\right)^{2}=0.381$ which means Job Satisfaction contributes to the Commitment to the Organization of $38.1 \%$. c. There is a very significant positive relationship between Transformational Leadership and Job Satisfaction with Commitment to the Organization as indicated by the correlation coefficient $\left(\mathrm{ry}_{12}\right)=0.622$ and the coefficient of determination $\left(\mathrm{ry}_{12}\right)^{2}=0.387$ which means Transformational Leadership and Job Satisfaction contribute to the Commitment to the Organization as big as $38.7 \%$.
\end{abstract}

Keywords: Transformational Leadership, Job Satisfaction, Commitment to the Organization.

\section{INTRODUCTION}

Education is an effort that is done deliberately and planned in the framework of the realization of a learning process that aims to improve knowledge, body and morals of students, so that it can be useful for themselves, society, nation, state, and religion. The education process will be quality if the coordination and management between teachers, curriculum, infrastructure are carried out in a harmonious and integrated manner, then it will produce a enjoyable learning situation and then produce high school performance. Teachers in this case play an important role in achieving quality education, the role of the teacher is not only to deliver knowledge to students but also to act as an education administrator. In managing the teacher's school, aside from being an implementation of the teaching and learning process, it also participates in participating in school organizations in order to achieve better school performance. Thus the teacher is required to behave and have a work attitude that plays an active role towards the achievement of school goals, namely Commitment to the Organization. A good commitment to the Organization will certainly have a good impact on schools, among others, 1) improving school performance, 2) improving teacher work discipline, 3) establishing a harmonious work climate, 4) improving the ability of principals to maintain education staff and education staff loyal there is a school organization, 5) increasing teacher responsibility in making school administration.

Jerald Greenberg and Robert A. Baron (2007) stated that organizational commitment is the extent to which an individual identifies himself as being involved in organizational activities and does not want to leave his organization. The commitment organizational factors are: a) Continuance Commitment, a commitment in which individuals tend to continue working in an organization because it must do so, b) Affective Commitment, a commitment where individuals will continue to work for the organization because they agree with the goals and values of the organization, c) Normative Commitment, a commitment in which the individual remains in the organization because of the social obligations that must be done.

Linda K. Stroh et al. (2002) states organizational commitment is a relative strength of identification of the involvement of individuals in a particular organization. Organizational commitment is a series of ongoing processes through organizational 
factors by showing their expressions of feeling in achieving organizational success and welfare in their place.

Hellriegel and Slocum (2011) suggested that employees who work longer hours are more likely to be committed than employees who work for shorter periods of time. If an employee has worked for a long time in an organization, to decide to leave the organization is not an easy decision. The characteristics of a strong commitment to the organization include: (a) support and accepting the goals and values of the organization, (b) wanting and doing something with all the effort on behalf of the organization, (c) wanting to always stay in the organization.

Transformational leaders become inspiration and encouragement for their followers in order to achieve maximum results, besides developing the capacity of the leadership qualities of their followers. Transformational leaders to grow and develop their followers to be leaders, with understanding personal needs through empowering and integrating personal goals and objectives of followers, groups and organizations.

Transformational leaders inspire followers to go beyond their personal interests for the benefit of the organization. They pay attention to the needs and interests of their followers. Changing the views of followers to see old problems into new ways, inspiring their followers to make more efforts to achieve their group goals (Robbins and Judge, 2014). Schermerhorn et al (2002) argues that there are four dimensions of transformational leadership, namely: (a) charisma (charisma), by giving an understanding of vision and mission and instilling a sense of pride and respect and trust in the followers. (b) inspiration, high expectations are communicated using symbols to focus effort and easily explain important goals. (c) intellectual motivator (intellectual stimulation), by increasing intelligence, rationality and solving problems carefully. (d) individual attention, such attention is given individually to treat individuals individually and provide training and advice.

Transformational leadership according to Spector (2008) is a leader who does something that can inspire others to adopt high goals and strive to achieve their goals. The leader of this model will convey the vision and motivate his followers to achieve that vision. Transformational leaders can convince their followers of their competence. Besides that the leader has the behavior to be able to form his followers to be creative, innovative, and trustworthy.

Job satisfaction is important for the realization of quality work because if a teacher has a high level of job satisfaction, he will show a good attitude towards his work. Robbin and Judge (2014) suggest that job satisfaction is a positive feeling about his work, which results from an evaluation of his characteristics. A person with a high level of job satisfaction has a positive feeling about his job, while someone with a low level has a negative feeling. Greenberg and Baron (2003) argue that job satisfaction is a reaction of positive or negative attitudes that individuals give to their work. According to Keith David and John Newstorm (2008) job satisfaction is an employee's feeling of work that is pleasant or unpleasant. According to Gibson, Ivancevich and Donnelly (2003) suggested that "Job satisfaction is an attitude that individuals have about their work, this results from their perception of their work based on work environment factors, such as supervisor style, policies and procedures, group affiliation work, working conditions and benefits "According to Robert Keitner and Kinicki (2014) job satisfaction reflects the degree to which a person likes his job. If formally defined, job satisfaction is an affective or emotional response to various aspects of work. This definition implies that job satisfaction is not a unified concept. But someone can feel quite satisfied with one aspect of his work and feel less satisfied with one or several other aspects. According to Colquitt et al (2011) suggests that job satisfaction is one of the individual mechanisms that directly affect job performance

\section{RESEARCH METHODS}

This research is a type of causality research with a quantitative approach which aims to determine the causal relationship, between commitment to the organization $(\mathrm{Y})$ and independent variables : Transformational leadership $\left(\mathrm{X}^{1}\right)$ and Job Satisfaction $\left(\mathrm{X}^{2}\right)$. The population of this study were private junior high school teachers in Bogor Regency from 40 sub-districts with 538 schools, and 4226 GTY teachers after being calculated by multistage random sampling method with 240 teachers. Data collection techniques in this study using a questionnaire. Respondents of this study were Permanent Teachers of the Foundation in the District Private Middle School. Bogor. The scale used is using a Likert scale.

Validity Test is used to determine whether a questionnaire is valid or not. Validity test is done comparing $r$ count with $r$ table. If $r$ count $>r$ table and is positive then the variable is valid, whereas if $r$ count $<r$ table then the variable is invalid (Ghozali, 2011). Test Validity by using the Pearson coefficient formula with $\alpha=0.05$, then comparing the $r$ count with $r$ table from the score of 40 questions tested. If $r$ count $>r$ table, the question or statement item is declared valid. Where $r$ count> $r$ table 0.197 .

Reliability test is a tool to measure a questionnaire which is an indicator of the variable or construct of a questionnaire is said to be realistic or reliable if the respondent's answer is consistent or stable over time. SPSS provides facilities to measure reliability with Cronbach alpha statistical tests. A construct or variable is said to be reliable if it gives a 
Cronbach alpha value> 0.70 (Ghozali, 2011). The result is the calculation of data $\mathrm{r}$ count $0.883 \mathrm{Y}$, $0.930 \mathrm{X}_{1}, 0.898 \mathrm{X}_{2}>0.70$ then the instrument is declared reliable and can be used as a data collection tool.

Requirements for analysis are data that are in the normal distribution and independent or independent variables $\left(X_{1}\right.$ and $\left.X_{2}\right)$ homogeneous to the dependent or dependent variable $(\mathrm{Y})$. The analytical requirements test used in this dissertation research consists of:

\section{a) Estimated Default Error Normality Test}

This test is to determine the normal or not distribution in the study. The normality test used is the Liliefors test with the help of Table L Estimated standard error is stated normal if the price of Calculate $<\mathrm{L}_{\text {table }}$ is tested with a significance level of 0.05 .

b) Homogeneity Test

This test is intended to examine the similarity of the population variance that is normally distributed. The homogeneity test used is the Kolmogorov-Smirnov test. Variance is declared homogeneous if the A symbol value is $>0.05$ with a significance level of 0.05 .

Statistical Data Hypothesis Test

1) Simple Regression Test

That is to find out the functional relationship between variables $\mathrm{X}^{1}$ and $\mathrm{X}^{2}$ with variable $\mathrm{Y}$.

2) Multiple Regression Test

Using multiple regression to determine the functional relationship between variables $X^{1}$ and $X^{2}$ together with variable $\mathrm{Y}$.

3) Simple Correlation Test

Meant to see the relationship between variables $X^{1}$ and $\mathrm{X}^{2}$ with the dependent variable $(\mathrm{Y})$ using Product Moment correlation. This simple correlation is to test the degree of relationship between the first and second hypotheses.

4) Multiple Correlation Test

This test is intended to test the second hypothesis which aims to see whether the correlation is meaningful if the two independent or more variables are correlated with the dependent variable (Y).

5) Determination Test

Analysis of the coefficient of determination (meaning) to determine the contribution or role of variables $\mathrm{X}^{1}$ and $\mathrm{X}^{2}$.

\section{RESULTS AND DISCUSSION}

\section{Requirements Analysis}

The normality test is used to determine the distribution of data,whether the data is normally distributed or not. Normality test using the Liliefors test. The results of the calculation of the normality of estimated error $\mathrm{Y}-\dot{\mathrm{Y}}^{2}$ obtained $\mathrm{L} 0=0.054$, while it was $\mathrm{Lt}=0.057$. Based on the normal test requirements, $\mathrm{L} 0$ $<\mathrm{Lt}$, it can be interpreted that the default error value of
Y-over 2 estimates comes from a population that is normally distributed.

Table1. Summary table The estimated normality error estimation using the Liliefors formula

\begin{tabular}{|c|c|c|c|c|c|}
\hline No & Galat & $\mathrm{L}_{0}$ & $\begin{array}{c}\mathrm{Lt} \\
(\alpha=0,05: \mathrm{n}=240)\end{array}$ & $\begin{array}{c}\mathrm{Lt} \\
(\alpha=0,01: \mathrm{n}=240)\end{array}$ & Conclusion \\
\hline 1 & $\mathrm{Y}-\dot{\mathrm{Y}}^{1}$ & 0,045 & 0,057 & 0,067 & Normal \\
\hline 2 & $\mathrm{Y}-\dot{\mathrm{Y}}^{2}$ & 0,054 & 0,057 & 0,067 & Normal \\
\hline \multicolumn{5}{|c|}{ Normal Requirement $: \mathrm{L}_{0}<\mathrm{L}_{\mathrm{t}}$} \\
\hline
\end{tabular}

Supardi U.S (2012)

\section{Homogeneity Variance Test}

Homogeneity of variance in Job Satisfaction data $\left(\mathrm{X}^{2}\right)$ on Organizational Commitment $(\mathrm{Y})$ was tested using the Levene Statistic test researchers using SPSS for Windows version 23 for data processing. Based on the calculation results obtained a significance value of $\mathrm{X}^{2}=0.782$, where the significance of $X^{2}$ is $0.782>0.05$, it is significant or the population is Homogeneous.

Table 2. Summary Table of Homogeneity Test Variance of Commitment to Organization (Y) above, Transformational Leadership $\left(\mathrm{X}_{1}\right)$ and Job Satisfaction $\left(\mathrm{X}_{2}\right)$ using Levene Statistic Test

\begin{tabular}{|c|c|c|c|c|c|}
\hline \multirow[b]{2}{*}{ No } & \multirow[b]{2}{*}{ Grouping } & \multirow{2}{*}{$\begin{array}{c}\text { Total } \\
\text { Sample }\end{array}$} & \multicolumn{2}{|c|}{$\chi^{2}$} & \multirow[b]{2}{*}{ Conclusion } \\
\hline & & & $\begin{array}{c}\text { Significant } \\
\text { Count }\end{array}$ & Significant & \\
\hline 1 & $\begin{array}{c}\text { Variable } \\
\mathrm{X}^{1} \text { over Y }\end{array}$ & 240 & 0,20 & 0,05 & Homogeneous \\
\hline 2 & $\begin{array}{c}\text { Variable } \\
\mathrm{X}^{2} \text { over } \mathrm{Y}\end{array}$ & 240 & 0,782 & 0,05 & Homogeneous \\
\hline \multicolumn{6}{|c|}{ Significance of Count $>0.05$ then Homogeneous population } \\
\hline
\end{tabular}

To test whether the regression equation is linear or non-linear, Linearity Test is needed by $\mathrm{F}$ test. The linearity equation of the regression equation is done by $\mathrm{F}$ test, that is the regression equation is linear if $\mathrm{F}_{\text {count }}<\mathrm{F}_{\text {table. Based on the }}$ calculation results contained in the table obtained the value of $\mathrm{X}^{1} \mathrm{~F}_{\text {count }}=0.128$ while $\mathrm{F}_{\text {table }}=2.409$ thus the regression equation $\dot{Y}=64.421+0.462 \mathrm{X} 1$ is linear and obtained the value of $\mathrm{X}^{2} \mathrm{~F}_{\text {count }}=0.030$ while $\mathrm{F}_{\text {table }}=2.409$ thus the regression equation persamaan $=46.921+0.624 \mathrm{X}^{3}$ is linear.

Table 3. Summary Table Variance Analysis Linearity Test Regression Equation Commitment to Organization $(Y)$ on Transformational Leadership ( $\left.\mathrm{X}^{1}\right)$ and Job Satisfaction $\left(\mathrm{X}^{2}\right)$

\begin{tabular}{|c|c|c|c|c|c|c|}
\hline \multirow{2}{*}{ No } & \multirow{2}{*}{$\begin{array}{l}\text { Relations } \\
\text { between } \\
\text { Variables }\end{array}$} & \multirow{2}{*}{ Regression Equations } & \multicolumn{3}{|c|}{$\begin{array}{l}\text { Linearity of Regression } \\
\text { Equations }\end{array}$} & \multirow{2}{*}{ Conclusion } \\
\hline & & & $F_{\text {cosent }}$ & $\mathrm{F}_{\text {abse }}$ & $\mathrm{F}_{\text {table }}$ & \\
\hline 1. & $\mathrm{Y}$ over $\mathrm{X}_{1}$ & $\dot{\mathrm{Y}}=64,421+0,462 \mathrm{X}_{1}$ & 0,128086 & 2,409 & 3,39 & $\begin{array}{c}\text { Non } \\
\text { Significant } \\
\text { Linier }\end{array}$ \\
\hline 2. & $\mathrm{Y}$ over $\mathrm{X}_{2}$ & $\dot{\mathrm{Y}}=46,921+0,624 \mathrm{X}_{2}$ & 0,030021 & 2,409 & 3,39 & $\begin{array}{c}\text { Non } \\
\text { Significant } \\
\text { Linier }\end{array}$ \\
\hline
\end{tabular}


Based on the calculation, the regression equation is obtained between variables $\mathrm{Y}$ and $\mathrm{X}$ and the significance test. The functional relationship between $\mathrm{X}$ and $\mathrm{Y}$ can be displayed in the form of a regression equation as follows: $\dot{Y}=64,421+0,462 \mathrm{X}^{1}$ and value $\dot{\mathrm{Y}}$ $=46,921+0,624 \mathrm{X}^{2}$ to test the hypothesis that there is a positive relationship between Transformational Leadership $\left(\mathrm{X}^{1}\right)$ and Commitment to Organization (Y) also needed a test of significance and linearity of the regression equation by using $\mathrm{F}$ test. The requirements of the hypothesis are tested if $F_{\text {count }}>F_{\text {table }}$.

It can be concluded that the relationship between Transformational Leadership variables $\left(\mathrm{X}^{1}\right)$ and Organizational Commitment (Y) is very significant. And the value of $\mathrm{X}^{2}$ obtained the value of $\mathrm{F}_{\text {count }}=93.61$ while $\mathrm{F}_{\text {table }}(\alpha=0.05)=2.410$. So it can be concluded that the relationship between the variables of Job Satisfaction $\left(\mathrm{X}^{2}\right)$ with Commitment to Organization $(\mathrm{Y})$ is very significant.

While the results of the simultaneous regression test are: $\dot{Y}=43.066+0.101 \mathrm{X}^{1}+0.543 \mathrm{X}^{2}$, the regression constant or $\alpha$ (intercept) is 43.066 , and the regression coefficient (slope) b1 is 0.101 and b2 is 0.543 . The requirements of the hypothesis are tested if $\mathrm{F}_{\text {count }}>\mathrm{F}_{\text {table. }}$. The results of the calculation of the regression significance test as shown in the table obtained the value of $F_{\text {count }}=74.807$ while $F_{\text {table }}(\alpha=$ $0.05)=2.41$. This shows that the relationship between Transformational Leadership variables $\left(X^{1}\right)$, Job Satisfaction $\left(\mathrm{X}^{2}\right)$ together with Commitment to Organization $(\mathrm{Y})$ is very significant.

Table 4. Recapitulation Table of Hypothesis Test Results

\begin{tabular}{|c|l|c|c|c|c|}
\hline \multirow{2}{*}{ Hypothesis } & \multirow{2}{*}{ Regression Equations } & \multicolumn{3}{|c|}{$\begin{array}{c}\text { Significance of } \\
\text { Regression Equations }\end{array}$} & \multirow{2}{*}{ Conlusion } \\
\cline { 3 - 5 } & & $\mathrm{F}_{\text {count }}$ & $\begin{array}{c}\mathrm{F}_{\text {table }} \\
(0,05)\end{array}$ & $\begin{array}{c}\mathrm{F}_{\text {table }} \\
(0,01)\end{array}$ & \\
\hline $\begin{array}{c}\text { no-1 } \\
\mathrm{Y}-\mathrm{X}^{1}\end{array}$ & $\dot{\mathrm{Y}}=64,421+0,462 \mathrm{X}^{1}$ & 81,36 & 2,41 & 3,4 & $\begin{array}{c}\text { Very } \\
\text { significant }\end{array}$ \\
\hline $\begin{array}{c}\text { no }-2 \\
\text { Y- } \mathrm{X}^{2}\end{array}$ & $\dot{\mathrm{Y}}=46,921+0,624 \mathrm{X}^{2}$ & 93,61 & 2,41 & 3,4 & $\begin{array}{c}\text { Very } \\
\text { significant }\end{array}$ \\
\hline $\begin{array}{c}\text { no }-3 \\
\mathrm{Y}-\mathrm{X}^{12}\end{array}$ & $\dot{\mathrm{Y}}=43,066+0,101 \mathrm{X}^{1}+0,543 \mathrm{X}^{2}$ & 74,87 & 2,41 & 3,4 & $\begin{array}{c}\text { Very } \\
\text { significant }\end{array}$ \\
\hline
\end{tabular}

\section{CONCLUSION}

There is a very significant positive relationship between Transformational Leadership and Commitment to the Organization as indicated by the correlation coefficient ( $\left.\mathrm{ry}^{1}=0.505\right)$ and the determination coefficient of $\left(\mathrm{ry}^{1}\right) 2=0.255$ which means Transformational Leadership contributes to the 25.5 Commitment to the Organization \% and supported by the regression equation $\dot{Y}=64,421+0,462 X^{1}$. Thus the data shows a positive relationship between Transformational Leadership and Commitment to the Organization. This means that if the value of the Transformational Leadership variable $\left(X^{1}\right)$ increases then the variable value of the Commitment to Organization (Y) increases.
There is a very significant positive relationship between Job Satisfaction with Commitment to the Organization as indicated by the correlation coefficient $\left(\mathrm{ry}^{2}\right)=0.618$ and the determination coefficient of $\left(\mathrm{ry}^{2}\right) 2=0.381$ which means Job Satisfaction contributes to the Commitment to the Organization of $38.1 \%$ and supported by the regression equation $\dot{Y}=46,921+0,624 X^{2}$. Thus the data shows a positive relationship between job satisfaction and commitment to the organization. This means that if the value of the Job Satisfaction variable $\left(\mathrm{X}^{2}\right)$ increases then also increases the Variable Value of Commitment to the Organization (Y).

There is a very significant positive relationship between Transformational Leadership and Job Satisfaction with Commitment to the Organization as indicated by the correlation coefficient $\left(\mathrm{ry}^{12}\right)=0.622$ and the coefficient of determination $\left(\mathrm{ry}^{12}\right)^{12} 2=0.387$ means Transformational Leadership and Job Satisfaction contribute to the Commitment to the Organization at $38.7 \%$ and supported by the regression equation $\dot{Y}=43.066+0.101 \mathrm{X}^{1}+0.543 \mathrm{X}^{2}$. Thus the data shows a positive relationship between Transformational Leadership and Job Satisfaction with Commitment to the Organization. This means that if the value of the Transformational Leadership variable $\left(\mathrm{X}^{1}\right)$ and Job Satisfaction $\left(\mathrm{X}^{2}\right)$ together increases then the Variable Value of Commitment to the Organization increases $(\mathrm{Y})$.

\section{REFERENCES}

Colquitt, Jason A., Jeffery A. Lepine, and Michael J. Wesson. 2009. Organizational Behaviour Improving Performance and Commitment in the Workplace. New York: Mc Graw-Hill.

Gibson, James L., John M. Ivancevich, James H. Donelly Jr, \& Robert Konopaske. 2006. Organizational : Behavior, Structure, Processes. New York: Mc Graw-Hill, Irwin.

Greenberg, Jerald dan Robert A. Baron. 2008, Behavior in Organizations, New Jersey : Pearson Education International.

Kreitner, Robert dan Angelo Kinicki. 2008. Organizational Behavior ( $8^{\text {th }}$ ed). Boston: Mc Graw-Hill.

Newstrom, John W. And Keith Davis. 1997. Organizational Behavior. New York: The McGraw-Hill Companies, Inc.

Stroh, Linda K., Gregory Northcraft \& Margaret A. Neale. 2002. Organizational behavior: a management challenge. (3rd ed). Mahwah, New Jersey: Lawrence Erlbaum Associates, Inc., Publishers. 